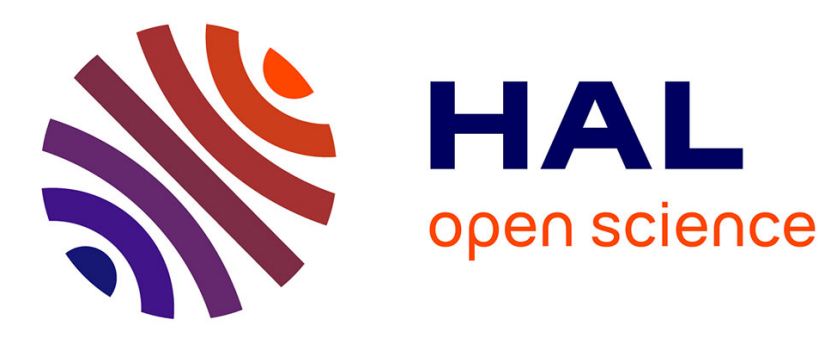

\title{
Liturgical Celebration and Theological Exegesis: the Easter Homilies of Gregory of Nyssa \\ Matthieu Cassin
}

\section{To cite this version:}

Matthieu Cassin. Liturgical Celebration and Theological Exegesis: the Easter Homilies of Gregory of Nyssa. "If Christ has not been raised..." Studies on the Reception of the Resurrection Stories and the Belief in the Resurrection in the Early Church, 115, Vandenhoeck \& Ruprecht, pp.149-165, 2016, Novum Testamentum et Orbis Antiquus/ Studien zur Umwelt des Neuen Testaments, 9783525593745. halshs-01409064

\section{HAL Id: halshs-01409064 https://shs.hal.science/halshs-01409064}

Submitted on 5 Dec 2016

HAL is a multi-disciplinary open access archive for the deposit and dissemination of scientific research documents, whether they are published or not. The documents may come from teaching and research institutions in France or abroad, or from public or private research centers.
L'archive ouverte pluridisciplinaire HAL, est destinée au dépôt et à la diffusion de documents scientifiques de niveau recherche, publiés ou non, émanant des établissements d'enseignement et de recherche français ou étrangers, des laboratoires publics ou privés. 


\section{V\&R Academic}




\section{Novum Testamentum et Orbis Antiquus/ Studien zur Umwelt des Neuen Testaments}

In cooperation with the "Bibel und Orient" foundation,

University of Fribourg/Switzerland.

Edited by Martin Ebner (Bonn), Peter Lampe (Heidelberg), Stefan Schreiber (Augsburg) and Jürgen Zangenberg (Leiden)

\section{Advisory Board}

Helen K. Bond (Edinburgh), Raimo Hakola (Helsinki), Thomas Schumacher (Fribourg), John Barclay (Durham), Armand Puig i Tàrrech (Barcelona), Ronny Reich (Haifa), Edmondo F. Lupieri (Chicago), Stefan Münger (Bern)

Volume 115

\section{Vandenhoeck \& Ruprecht}


Joseph Verheyden/Andreas Merkt/Tobias Nicklas (eds.)

\section{"If Christ has not been raised ..."}

Studies on the Reception of the Resurrection Stories and the Belief in the Resurrection in the Early Church

Vandenhoeck \& Ruprecht 
Bibliographic information published by the Deutsche Nationalbibliothek The Deutsche Nationalbibliothek lists this publication in the Deutsche Nationalbibliografie; detailed bibliographic data available online: http://dnb.d-nb.de.

ISSN $1420-4592$

ISBN 978-3-647-59374-6

You can find alternative editions of this book and additional material on our Website: www.v-r.de

๑) 2016, Vandenhoeck \& Ruprecht GmbH \& Co. KG, Theaterstraße 13, D-37073 Göttingen/ Vandenhoeck \& Ruprecht LLC, Bristol, CT, U.S.A.

www.v-r.de

All rights reserved. No part of this work may be reproduced or utilized in any form or by any means, electronic or mechanical, including photocopying, recording, or any information storage and retrieval system, without prior written permission from the publisher. 


\section{Inhalt}

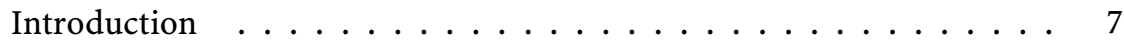

Meinolf Vielberg

Tod und Jenseits in der spätrepublikanischen und augusteischen

Literatur der Römer . . . . . . . . . . . . . . . . . . . . . 11

\section{Riemer Roukema}

The Resurrection according to 1 Corinthians 15:35-55 as Understood and Debated in Ancient Christianity $\ldots \ldots \ldots 33$

Hagit Amirav/Emiliano Fiori

Early Interpretations of Ephesians 5:14: Patristic Concepts of the

Resurrection in Literal and Allegorical Circles . . . . . . . . . . . 61

Martin Meiser

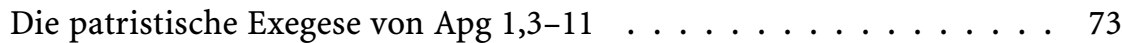

Tobias Nicklas

Auferstehung zu Tod und Strafe: Unpaulinische

Auferstehungsvorstellungen im frühen Christentum . . . . . . . . 105

Mark Edwards

Markus Vinzent on the Resurrection . . . . . . . . . . . . . . 123

Cornelis Hoogerwerf

Proving the Resurrection of the Flesh

The Use of Natural Philosophy and Galenic Epistemology in

Pseudo-Justin's De Resurrectione . . . . . . . . . . . . . . . . . . 135

Matthieu Cassin

Liturgical Celebration and Theological Exegesis: the Easter Homilies of

Gregory of Nyssa . . . . . . . . . . . . . . . . . . . . . 149 
Harald Buchinger

Die Bedeutung der Auferstehung für Termin, Gestalt und Gehalt der ältesten Osterfeier ． . . . . . . . . . . . . . . . . . . 167

Andreas Merkt

Writing Over the Dead Body

Ancient Christian Grave Inscriptions and the Idea of Resurrection . . 199

List of Abbreviations . . . . . . . . . . . . . . . . 217

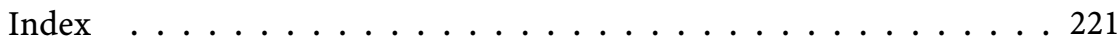




\section{Introduction}

The present volume contains the proceedings of the fourth symposium of the Novum Testamentum Patristicum project (NTP), an international research project on the reception history of the New Testament in the early Church. The symposium was held in October 2012 at the University of Leuven. It was organised by Joseph Verheyden, Tobias Nicklas, and Andreas Merkt, the coordinators of NTP. The topic of the meeting was the reception of the resurrection and empty tomb stories and the development of the belief in resurrection in the early Church.

The belief in the resurrection constitutes the core issue of Christianity and of Christian tradition. The earliest references to the resurrection and witnesses to such a belief are found in the canonical gospels and in the letters of Paul, but the topic obviously remained of the utmost importance all through the early Church. It would be impossible to try and cover the full evidence for the reception of the resurrection stories in the early Church in just one volume, and this was never the intention of the organisers of the conference. As a consequence, what this volume offers is not "the story" of this reception, but rather "studies" on the topic, as indicated in the title of the book. The selection was guided by two principles. As was the case also in previous NTP conference volumes, the editors wished to give a forum to colleagues who are writing a commentary on a particular New Testament book to show the results of their work so far to a larger readership. In addition, the editors also wished to give a place to such contributions that open a broader perspective, be it the Roman world, or other aspects of Christian life and praxis than the writings of homilists and commentators. That said, it should be noted that the volume contains contributions on at least some of the more important texts on the topic and has tried to pay attention to aspects that are perhaps not always immediately put in the picture when dealing with the resurrection accounts.

Overall, the material can be divided into three parts:

(1) the reception history of particular passages. The two crucial passages in Paul's letters are studied by R. Roukema (1 Cor 15) and by H. Amirav and E. Fiori (Eph 5). Roukema is the author of the commentary on the reception of 1 Corinthians for NTP. Amirav co-authors the commentary on Ephesians. The opening verses of Acts are dealt with by M. Meiser, who is responsible for the NTP commentary on Acts. Roukema focuses on the 
controversy that was raised by the ambiguities in Paul's representation of the status of the resurrected body. Amirav and Fiori note that the early Christian authors were rather more interested in the moral dimension of the call in Eph 5:14 than in its eschatological potential. The same concern for bringing out the ethical dimension can be seen in the commentaries on Acts 1:3-11, though in this instance not infrequently combined with or alongside a more spiritual reading of the ascension and its significance for the salvation of the Christian. Taking his clue from two passages in the Book of Revelation (Rev 2:11 and 20:6, 14), T. Nicklas, responsible for the NTP commentary on Revelation, shows how the prime interest in these passages and in later authors is not with salvation, but with how the resurrection prepares the way for the final judgement that is to come. This connection between liberation from the death and facing judgement may surprise, but shows that a number of Christian groups and traditions thought rather differently about the resurrection and its aim and effects than what can be read in Paul's Letter to the Corinthians.

(2) the way the theme of resurrection was dealt with in early Christian authors and praxis. M. Edwards offers a critical reading of M. Vinzent's 2011 monograph on the resurrection, in which it is argued that Paul had been largely forgotten about in first decades of the second century and, perhaps even more controversial, that Marcion authored the first real gospel. C. Hoogerwerf contributes an essay on Pseudo-Justin's De resurrectione that was not read at the conference, but adds a nice example of how early Christian authors looked for arguments and evidence for their position in Hellenistic philosophy and, more particularly, epistemology to make a case in defence of the Christian view on resurrection. M. Cassin studies the Easter homilies of Gregory of Nyssa and comes to the slightly surprising conclusion that the homilist's main interest is not in the resurrection accounts as such, but that he develops his thought with an eye on the liturgical praxis and on the exegetical tradition that linked the significance of the stories primarily with the salvation of the believer and less with rescuing Jesus from death. The liturgy is also the focus of $\mathrm{H}$. Buchinger who offers a superb survey of the Easter homilies material and the way these have incorporated or inform about liturgical praxis in Easter time.

(3) the broader context, including the non-Christian background. The latter issue is dealt with in the opening essay by M. Vielberg, who compares Christian Easter expectations with similar but more politically oriented expectations that were fabricated and promoted under the reign of Augustus. A. Merkt focuses on another aspect of Christian life when studying evidence from tomb inscriptions reflecting on the Christians' belief in the afterlife and its connection with this life and the ethical requirements or expectations it involves. 
The conference brought together biblical scholars and specialists of early Christian studies for a dialogue that was meant to widening the perspectives. Several of the contributors have pointed out the complexity of the issue at stake because the resurrection stories and the belief they wish to raise or express bring forth a number of dogmatic and historical questions that many later on had great difficulties to harmonise.

The editors wish to thank the Flemish Research Foundation (FWO) for a generous grant, the editorial board of "Novum Testamentum et Orbis Antiquus" for accepting also this conference volume in the series, as they did with previous ones, and Vandenhoeck \& Ruprecht publishing house for a fruitful cooperation in getting the manuscript published.

Joseph Verheyden 
(C) 2016, Vandenhoeck \& Ruprecht GmbH \& Co. KG, Göttingen ISBN Print: 9783525593745 — ISBN E-Book: 9783647593746 


\section{Liturgical Celebration and Theological Exegesis: the Easter Homilies of Gregory of Nyssa}

\section{General Background and Setting}

Gregory, bishop of Nyssa (around 335 - after 394) and one of the Cappadocian Fathers, is the author of an important corpus dealing with various aspects of Christian literature: theology, exegesis, spirituality. He used various literary genres: biblical commentaries, polemical treatises, letters, spiritual tracts, but also homilies. ${ }^{1}$ We currently know about his preaching activity thanks to 27 authentic sermons, published in three volumes of the Gregorii Nysseni opera series. $^{2}$ We should add to this total four series of exegetical homilies, respectively on Ecclesiastes, Song of Song, Beatitudes and Lord's Prayer. ${ }^{3}$ The non-exegetical homilies fall into the following categories: moral and social, funeral, hagiographic, liturgical. In the last category, there are seven homilies, ${ }^{4}$ three of which are directly linked to the celebration of Easter and authentic $;^{5}$ the homily In luciferam sanctam Domini resurrectionem (CPG 3177) is generally thought to be inauthentic. ${ }^{6}$

The present paper will, therefore, mainly deal with the three authentic homilies for Easter: In sanctum Pascha, De tridui spatio, In sanctum et salutare Pascha. ${ }^{7}$ I will first offer some background information before addressing the question of the place and usage of the Resurrection stories in them.

1 On Gregory's life, see P. Maraval, “Biography of Gregory of Nyssa”, in G. Maspero/L.F. MateoSeco (ed.), The Brill Dictionary of Gregory of Nyssa (Sup.VigChr 99; Leiden/Boston, MA, 2010) 103-16. For the abbreviations of Gregory's works, see F. Mann (ed.), Lexicon Gregorianum (Leiden, 1999-2014).

2 CPG 3147, 3156, 3168-3176, 3178-3192, 3194; Gregorii Nysseni Opera, vol. IX (Leiden, 1967), vol. X.1 (Leiden/New York, 1990), vol. X.2 (Leiden/New York/Köln, 1996). I do not take into account the pseudepigraphic homilies (CPG 3177, 3193, 3195).

3 CPG 3157 (8 homilies), 3158 (15 homilies), 3161 (8 homilies), 3160 (5 homilies).

4 CPG 3173-3176, 3178, 3191, 3194.

5 CPG 3174-3176.

6 See J. Daniélou, “Bulletin d'histoire des origines chrétiennes”, Recherches de science religieuse 55 (1967) 88-151, on p. 151; G.C. Stead, "Introduction”, in A. Spira/C. Klock (ed.), The Easter Sermons of Gregory of Nyssa, Translation and Commentary. Proceedings of the Fourth International Colloquium on Gregory of Nyssa, Cambridge, England: 11-15 September, 1978 (Patristic Monograph Series 9; Cambridge, MA, 1981) viI-viII, on p. viII. This text deserves a new and full examination.

7 On these homilies, see the proceedings of the 4th Gregory of Nyssa colloquium: Spira/Klock (ed.), The Easter Sermons of Gregory of Nyssa; see also E. Moutsoulas, "Les sermons pascaux de Gré- 
We have no definite and general chronology for Gregory's literary production, except for some of his works, ${ }^{8}$ such as the Contra Eunomium. Although scholars have regularly dealt with dating different works, there is currently no consensus on this matter. ${ }^{9}$ It is worth noting that in 1978, at the Fourth Gregory of Nyssa International Colloquium on Easter homilies, Gerhard May proposed a paper on the chronology of these homilies, but did not publish it since he considered it as "too tentative". ${ }^{10}$ Since then, one should mention P. Maraval's contribution to the Dictionary on Gregory, but this is mainly a partial synthesis of previous works. ${ }^{11}$ In the present context, the difficult question of dating the three homilies is perhaps less crucial. The majority of scholars dates them sometime between 375 and 394.

Hubertus Drobner has suggested dating De tridui spatio and the correlative In sanctum et salutare Pascha to the last years of Gregory of Nyssa. ${ }^{12}$ Taking into account the development of Gregory's thought on the topic of Christ's state in death, the earliest possible date would be 386. The Antirrheticus adversus Apolinarium could be a point of reference, but its date is not firmly established and nothing more can be said than that it is posterior to Contra Eunomium III (382-383). The other point of reference is the Oratio catechetica magna, but its date is hotly debated and varies from a little before 381 to

goire de Nysse", Theologia 51 (1980) 333-47; J. Rexer, Die Festtheologie Gregors von Nyssa. Ein Beispiel der reichskirchlichen Heortologie (Patrologia 8; Frankfurt/Berlin/Bern, 2002); D.A. Giulea, "The Cappadocian Paschal Christology: Gregory Nazianzen and Gregory of Nyssa and the Divine Paschal Image of Christ", ZAC 12 (2008) 477-503. See also the Italian translation with full introduction by E. Petrella, Gregorio di Nissa, Omelie del tempo pasquale (Storie e testi 18; Napoli, 2009).

8 J. Daniélou, "La chronologie des sermons de Grégoire de Nysse", RSR 29 (1955) 346-72; idem., "La chronologie des œuvres de Grégoire de Nysse", StPatr 7 (1966) 159-69; G. May, "Die Chronologie des Lebens und der Werke des Gregor von Nyssa", in M. Harl (ed.), Écriture et culture philosophique dans la pensée de Grégoire de Nysse. Actes du colloque de Chevetogne (22-26 septembre 1969) (Leiden, 1971) 51-67.

9 For the date of De s. Theodoro (CPG 3183), see C. Zuckerman, "The Cappadocians and the Goths", Travaux et mémoires 11 (1991) 473-87, on pp. 480-6; the author emends the dating proposed by Daniélou, "La chronologie des sermons", 355-6, and suggests 17 February 380. For another attempt about Mart. I, see J. Leemans, "On the Date of Gregory of Nyssa's First Homilies on the Forty Martyrs of Sebaste (Ia and Ib)", JTS 52 (2001) 92-7, who proposed to date these homilies to 375, but see also an inverse movement in J. Reynard, Grégoire de Nysse, Sur les titres des Psaumes, introduction, édition et traduction (SC 466; Paris, 2002), 14-15; this double movement is characteristic of the instability of the general chronology of Gregory's works in general and his homilies in particular. See also the remarks of P. Maraval, "Chronology of Works", in Maspero/Mateo-Seco (ed.), The Brill Dictionary of Gregory of Nyssa, 153-69, on p. 165.

10 Stead, "Introduction", viII.

11 Maraval, "Chronology of Works"; first publication in Spanish in 2006, in Italian in 2007.

12 H. R. Drobner, Die drei Tage zwischen Tod und Auferstehung unseres Herrn Jesus Christus, eingeleitet, übersetzt und kommentiert (Philosophia Patrum 5; Leiden, 1982); for the date, see Exkurs 2, "Die Datierung von De tridui spatio", 190-8. 
386-387 or later. ${ }^{13}$ It seems reasonable, then, to consider a later date in Gregory's ecclesiastical career, but nothing is settled. We will see that a new parallel with the Homilies on the Song also supports a later date.

Dating In sanctum Pascha is even harder. In fact, we have no concrete evidence for this homily. Jean Daniélou argued that "this homily can be set with certitude to Easter 379"; ${ }^{14}$ but his only argument is the thematic affinities with De hominis opificio. In fact, this is a rather weak argument, since such affinities exist in works of Gregory of Nyssa that have been written at some ten or fifteen years of distance, such as Contra Eunomium and In Canticum canticorum. ${ }^{15} \mathrm{G}$. Misago, proposed to date In sanctum Pascha at the same time as De anima et resurrectione, a work that he situated in $382 .{ }^{16}$ But again, the arguments are only based on thematic convergence and, worse, the date of $D e$ anima et resurrectione is not firmly established. ${ }^{17}$ It seems then that there is no firm ground to settle a date for this homily, except that it is perhaps posterior to De hominis opificio, so later than 379 .

The geographical setting of the three homilies is not any clearer. In fact, as the bishop of Nyssa, we may suppose that Gregory has preached regularly in his town. But we also know that he delivered sermons elsewhere in Cappadocia for Martyr's feasts (panegyreis), mainly in the sanctuary of the martyrs. ${ }^{18} \mathrm{He}$ surely preached in Constantinople during councils, ${ }^{19}$ but also for funeral orations of the imperial family. ${ }^{20}$ His moral, social and festal homilies are more difficult to locate. In fact, since Gregory travelled quite often in different regions, there is no clear geographical setting for his Easter homilies. Previous scholars have suggested various options for De tridui spatio. Some have proposed to locate it in Jerusalem, mainly because of the mention of the 'door

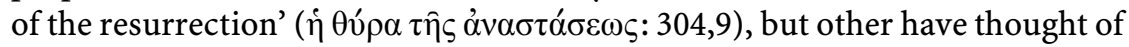
Constantinople, because of the high intellectual standard of the text, or of Nyssa, or of somewhere else in Asia Minor. ${ }^{21}$ We have in fact no evidence for locating any of these homilies. The last point to settle will be the liturgical background of the three homilies, but it has no meaning to speak of it without giving some hints of the content of these texts.

13 See for example R. Winling, Grégoire de Nysse, Discours catéchétique (SC 453; Paris, 2000), 125-30; see also Maraval, "Chronology of Works", 156.

14 Daniélou, "La chronologie des sermons", 350.

15 M. Cassin, L'écriture de la controverse chez Grégoire de Nysse. Polémique littéraire et exégèse dans le Contre Eunome (Études augustiniennes, série Antiquité 193; Paris, 2012), 291-2.

16 Cited by Maraval, "Chronology of Works", 162.

17 The only secure element is that the book is later than Macrina's death (July 379).

18 See for example De sancto Theodoro, In XL Martyres Ia-b.

19 De deitate adversus Evagrium, De deitate Filii et Spiritus sancti, Oratio funebris in Meletium.

20 Oratio consolatoria in Pulcheriam; Oratio funebris in Flacillam.

21 Drobner, Die drei Tage, 7. 


\section{Three Easter Homilies: Overall Description}

At first glance, the three homilies are very different one from another. In sanctum Pascha ${ }^{22}$ begins with a rather long and strongly articulated prologue in four parts: the first one starts from Ps 116:1, "Praise the Lord, all you nations, give him praise all you peoples". ${ }^{23}$ The second has its starting point in a liturgical acclamation, "Today, Christ rose". The third one begins with Ps 117:24, "This day that the Lord made, let us rejoice and be glad in it". The last part re-uses elements of 1 Cor 15; it opens on a parenesis and leads the listener to the main theme of the homily, the resurrection. The main body of the text, which is a bit longer than the prologue, proposes various arguments about the resurrection, in particular in connection with the Last Judgement; I will not deal with it in detail. The global trend of this part is not biblical. The epilogue opens on a double quotation, one from 1 Cor 15:52, "The trumpet shall sound and the dead shall rise up", and the other from John 5:28-29, "There come the hour when all those in the tombs shall hear his voice, and they shall come out, those who have done good things for the resurrection of life, and those who have practised bad things for the resurrection of judgement". This opening paves the way for a conclusion that goes back to the resurrection question, without a proper biblical or liturgical ending.

De tridui spatio has already been investigated in great detail at the 1978 Colloquium and then by Drobner in $1982 .{ }^{24}$ I only give the general structure of the text, even if there are still some uncertainties on its exact structure. ${ }^{25}$ As for In sanctum Pascha, there is first a long prologue, divided in two parts: the first one proposes a series of Old Testament testimonies, that is typoi of the Christian Easter feast. The second part presents the essential themes of the homily, mainly death and resurrection and the new creation. The main part of the speech deals with a set of questions that Drobner has divided, perhaps a bit

22 See the analysis of the text in M. Harl, "L'éloge de la fête de Pâques dans le Prologue du Sermon In Sanctum Pascha de Grégoire de Nysse (In Sanctum Pascha p. 245, 4-253, 18)", in Spira/Klock (ed.), The Easter Sermons of Gregory of Nyssa, 81-99, on pp. 83-5, accepted by A. Spira, "Der Descensus ad inferos in der Osterpredigt Gregors von Nyssa De tridui spatio (De tridui spatio p. 280, 14-286, 12)", in ibid., 195-261, on p. 201, against J.C.M. van Winden, "In Defense of the Resurrection (In Sanctum Pascha p. 253, 19-270, 7)", in ibid., 101-21, who stops the prologue at 245,15 .

23 For the anti-heretic and anti-Jewish reading of this verse, see J. Leemans, "Preaching and the Arian Controversy: Orthodoxy and Heresy in Gregory of Nyssa's Sermons", in J. Verheyden/ H.G.B. Teule (ed.), Heretics and Heresies in the Ancient Church and in Eastern Christianity. Studies in Honour of Adelbert Davids (Eastern Christian Studies 10; Leuven, 2011) 127-42, on p. 132.

24 Drobner, Die drei Tage. See also J. Reynard, "L'utilisation de l'Écriture dans le De tridui spatio", in M. Cassin/H. Grelier (ed.), Grégoire de Nysse: la Bible dans la construction de son discours. Actes du colloque de Paris, 9-10 février 2007 (Études augustiniennes, série Antiquité 184; Paris, 2008) 212-25.

25 See mainly Drobner, Die drei Tage, 13-14; 80 n. 238. 


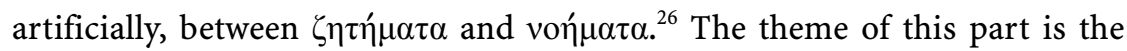
interval between the death and resurrection of Jesus, its modalities and time. I will only give a list of these topics, without laying stress on this twofold division. First, Gregory describes the descensus proper, when Christ descended into hell ${ }^{27}$ then, the author speculates on the duration of Jesus' death, which he counts as three days; thirdly, he offers a justification for this count, which is not obvious, as it is well known. Lastly, he proposes a solution for the state of Christ during these three days: the situation of his body and soul and his divinity. It is this theological point that has allowed scholars to speculate on the chronology of some of Gregory's works, mainly Contra Eunomium, Letter 3, Antirrheticus adversus Apolinarium and Oratio catechetica magna. ${ }^{28}$ Then, in what Drobner has isolated as a second part, Gregory discusses the relation between the Old Testament Passover narratives and rules (unleavened bread, bitter herbs and date of Passover according to the moon) and the Christian observance and the symbolic meaning of the cross. The epilogue goes back to the resurrection stories in a theatrical way, since the orator suddenly turns his speech toward a vivid and actualised description of the resurrection events and interprets them in order to actualize these actions in the Eucharist. We will come back later to this part of the speech, which is of direct interest for our purpose.

The last of the authentic homilies on Easter, In sanctum et salutare Pascha, ${ }^{29}$ may be read as a concluding speech coming from the same Easter celebration as De tridui spatio. ${ }^{30}$ Even if this point can be discussed, the general tone of the text is clear and in immediate contrast with the two other homilies. In sanctum et salutare Pascha is written like a liturgical hymn. Gregory focuses on the novelty of Easter, in a large series of antitheses about the ancient and the new condition. The biblical basis of the text is important, coming from both Old and New Testament, but there is no formal exegesis as in the two other homilies. We find again Ps 117:24, "This day that the Lord made", a classical Easter verse, but also a range of New Testament allusions in order to describe the new life after Christ's resurrection. This short homily ends on a series of quotations from the Psalms; it's a confirmation of the liturgical tone of the whole text.

26 Drobner, Die drei Tage, 127-8.

27 On this theme, see R. Gounelle, La descente du Christ aux enfers: institutionnalisation d'une croyance (Études augustiniennes, série Antiquité 162; Paris, 2000).

28 See Drobner, Die drei Tage, and previously J. Lebourlier, “À propos de l'état du Christ dans la mort", RSPT 46 (1962) 629-49 and 47 (1963) 161-80; see also J. Zachhuber, Human Nature in Gregory of Nyssa, Philosophical Background and Theological Significance (Sup.VigChr 46; Leiden/Boston, MA/Köln, 2000), 204-7.

29 On its structure, see Drobner, Die drei Tage, 168-9.

30 See E. Gebhardt, GNO IX (Leiden, 1967), 178; Spira, “Der Descensus ad inferos", 213, n. 44, on the basis of an unpublished work by H. Hörner; H.R. Drobner, Die drei Tage, 168. 


\section{The Resurrection Stories: Where, Why and How}

The first point to settle is that these Easter homilies do not tell the resurrection story itself. Gregory does not speak of the story of the resurrection or of the apparitions of Jesus after his resurrection, except, in a very peculiar way, at the end of De tridui spatio. There is neither a proper story of the Passion. We might have expected one, even if at the end of the 4th century, the distinction and particularization of each feast day of the Holy Week is in process. ${ }^{31}$ Even if De tridui spatio deals precisely with the three days between Maundy Thursday and Easter Sunday, there is no storytelling of the events; the story itself is always integrated in theological argumentation, and supposed to be evident to the listeners.

I will take as a starting point for my inquiry into Gregory's usage of the New Testament resurrection stories an element that draws us back into the narrative. In In sanctum Pascha, 247,26-248,27, the author gives a short sketch of the economy of the Incarnation and concentrates his attention on the Passion itself.

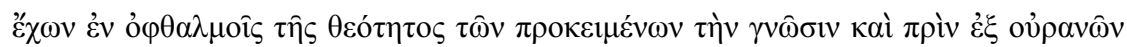

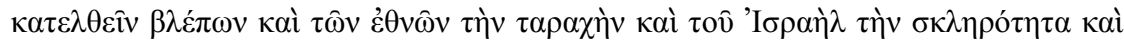

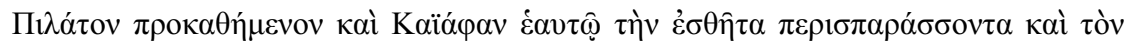

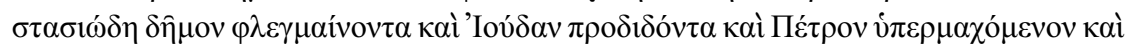

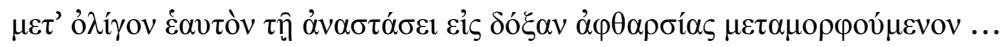

With eyes of godhead he had knowledge of what lay ahead, and saw, before his descent from heaven, the uproar of nations, the stubbornness of Israel, Pilate seated before him, Caiaphas tearing his clothes apart, the rebellious mob seething, Judas betraying, Peter fighting for him, and himself soon after transfigured by the resurrection into the glory of incorruption ... (Sanct. Pasch. 248,6-13). ${ }^{32}$

This summary looks like a cento of New Testament verses, but it is not a proper cento. There are thematic and narrative echoes from the New Testament, but very few verbal similarities. Here are some examples. The stubbornness of

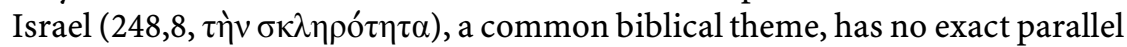
in the text of the Passion; the nearest parallel is Matt 19:8 about divorce. "Pilate seated before him" reminds us of a well-known scene, but the verb $\pi \rho \circ \alpha \theta \dot{\eta} \mu \varepsilon v o v(248,9)$ is absent from the New Testament; ${ }^{33}$ Matt 27:19 reads the simple form of кá $\theta \eta \mu \alpha$. Caiaphas "tearing his clothes apart" is a wellknown motif but strangely enough, it comes before the trial with Pilate in the

31 See for example the indications in Rexer, Die Festtheologie, 29-36.

32 All the translations of the three Easter homilies are from S. Hall, as published in Spira/Klock (ed.), The Easter Sermons of Gregory of Nyssa, 5-53.

33 And not frequent in the Old Testament, since it appears only four times (1 Esd 1:30; 5:60; 9:4, 45). 
New Testament narrative, not after (Matt 26:65 and 27:1, 11-26 and parallels), and the words used are not the same; $\pi \varepsilon \rho 1 \sigma \pi \alpha \rho \alpha ́ \sigma \sigma o v \tau \alpha(248,10)$ is extremely rare. ${ }^{34}$ The "rebellious mob" does not look strange, but Gregory's $\tau$ òv $\sigma \tau \alpha-$ $\sigma \iota \omega \delta \delta \eta \delta \eta \mu \nu ~ \varphi \lambda \varepsilon \gamma \mu \alpha i ́ v o v \tau \alpha$ is not found as such in the Passion narratives; the phrase $\delta \eta \bar{\mu} \varsigma_{\varsigma} \sigma \tau \alpha \sigma \iota \omega \delta \delta \zeta$ is used in Greek literature only by Gregory of Nyssa, here and in Castig. 316,19, and by Gregory of Nazianzus (Or. 4,86,14). In the same way, Judas' betrayal is described with $\pi \rho \circ \delta$ í $\delta \omega \mu$, when the New Testament generally prefers $\pi \alpha \rho \alpha \delta i \delta \omega \mu \mathrm{u}^{35}$ We only find a word on the $\pi \rho 0-$

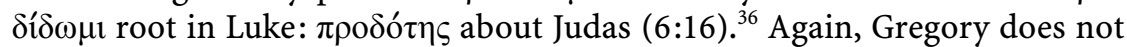
follow the narrative structure of the gospels account, since Judas' betrayal and Peter's fight for Jesus are out of place. For this last example, Gregory uses the verb $v \pi \varepsilon \rho \mu \alpha \alpha_{0} \mu \alpha 1$ that is not used at all in the Old or the New Testament.

This first example, therefore, suggests that Gregory heavily relies on the Passion narrative and does not extrapolate or add any element. But at the same time, he freely recomposes these narratives and does not necessarily use the proper words of the Gospels. He takes the scenes and stories, but not the words; moreover, he does not stick to the chronology of his sources. In this first example, it seems that this rewriting of the Passion has no precise aim or motivation.

The situation is quite different in the following lines. Gregory goes on with a brief mention of the resurrection: "and soon after transfigured by the

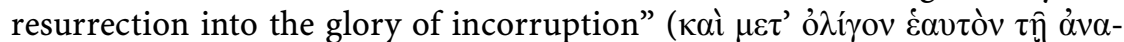

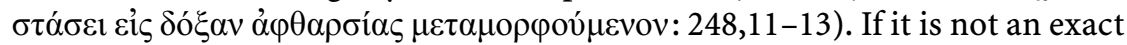
quotation of the Gospel, one can at least identify two Pauline verses behind the

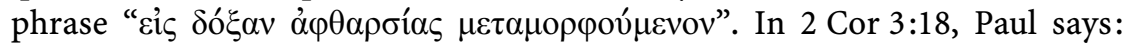

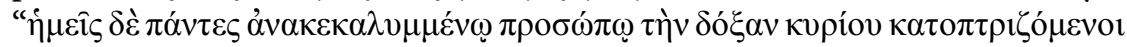

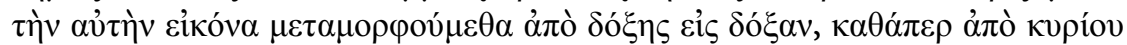

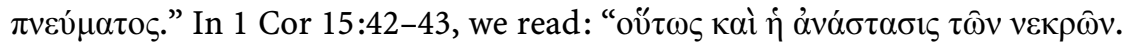

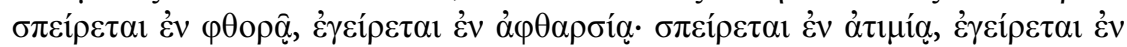
$\delta$ ó $\xi$.." Both verses deal with the resurrection of man, not that of Christ, as this is the case in Gregory. So the rewriting is probably a conscious one: Gregory is already preparing his transition from the resurrection of Christ to that of the faithful, hence to move from the Gospel account to its application to the audience.

At the very end of this section, Gregory evokes the descent of Christ in our human condition and his resurrection according to a simile that is typical of him but not really biblical: the danger one faces when plunging in a torrent in order to save someone who risks to sink. Again, even if the theme of the

34 John Philoponus, De aeternitate mundi, 106,9; Hesychius, Lexicon, A, 3998.

35 In Rom 11:35, the verb means "give before", with a temporal meaning of $\pi \rho 0-$. See 2 Macc 7:37; 4 Macc $4: 1 ; 6: 11$.

36 See also Acts 7:52; Rom 3:4. Cf. 2 Macc 5:15; 10:13, 22; 3 Macc 3:24. 
descent of Christ is, of course, a New Testament theme, there is no clear verbal echo of any Pauline or Gospel text, at least in the form of quotation or allusion.

This first example clearly shows that Gregory employs the passion and resurrection stories in a larger theological frame. There is no proper storytelling, but rather a purposeful rewriting of New Testament materials. This method supposes that the audience already knows the stories - or, at least, that the preacher supposes this to be the case. It also offers a confirmation of Gregory's method of preaching. It is not so much about the stories and emotions, but about their theological message.

Here is a second example from the core section of De tridui spatio

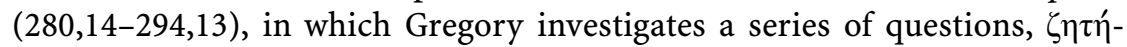
$\mu \alpha \tau \alpha$, about Jesus' passion and resurrection. The justification for the beginning of the three days interval offers a first hint of how he builds up his homily. The author locates the beginning of the three days of the prophecy in Matt 12:40 at the last supper without telling the story itself or providing any sort of setting.

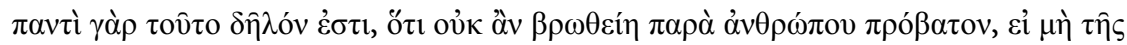

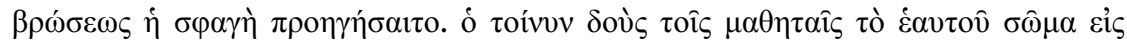

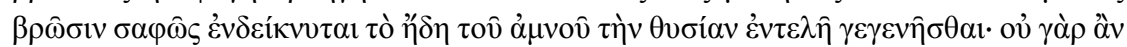

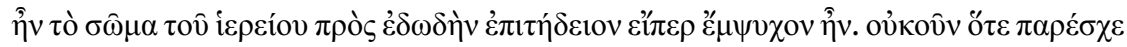

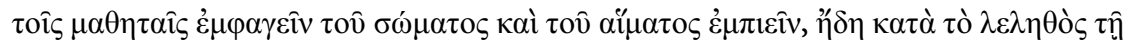

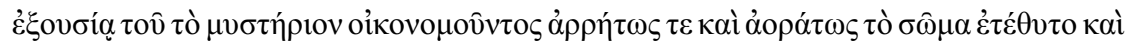

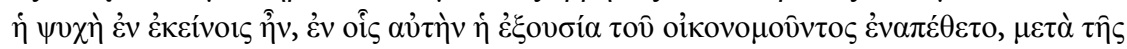

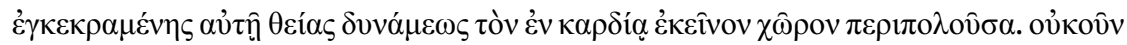

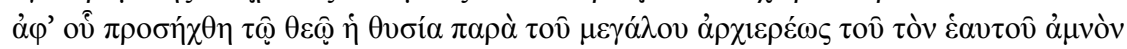

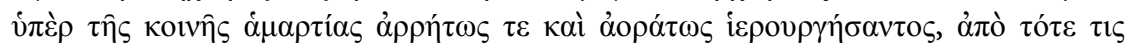

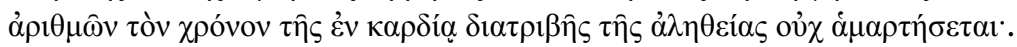

For it is clear to everyone that a sheep could not be eaten by a man unless the slaughter had preceded the eating. He then, who gave his own body to the disciples as food, plainly indicates that the sacrifice of the lamb is already complete. For the body of the victim would not be suitable for eating if it were still alive. So when he made his disciples share in eating his body and drinking his blood, already in secret by the power of the one who ordained the mystery his body had been ineffably and invisibly sacrificed and his soul was in those regions in which the authority of the ordainer had stored it, traversing that place in the "Heart" along with the divine power infusing it. Thus from the time when the sacrifice was offered to God by the Great Priest who ineffably and invisibly consecrated his own lamb for the general sin, if one counts from that point the period of the sojourn in the "Heart", one will not be far from the truth (Trid. spat. 287,17-288,13).

The Last Supper is interpreted through the frame of the Epistle to the Hebrews, as is testified by the mention of the High Priest (288,9-11).

Another example of this theological and hermeneutical use of the New 
Testament is found in the section in which Gregory argues about the time of the resurrection. Already before Gregory it was a debated question how to define the three days interval before the resurrection. H. Drobner offered a good status quaestionis and investigated the sources of Gregory on this topic. ${ }^{37}$ I just want to stress how the bishop of Nyssa presents this point: Severus of Antioch, whose homily on the discrepancies between the resurrection stories has been transmitted among Gregory's Easter homilies, ${ }^{38}$ chooses a radically different method. He starts from a possible contradiction, at least from discrepancies between the four Gospels, and then manages to solve the difficulty. Gregory, on the contrary, immediately offers his solution by selecting one Gospel, Matthew's, and forgoing the others:

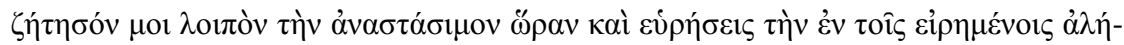

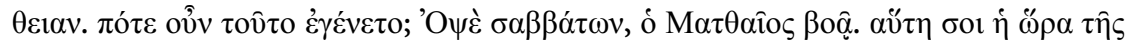

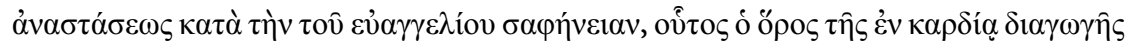

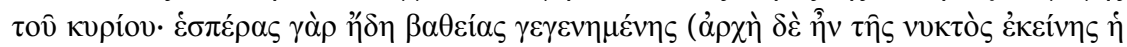

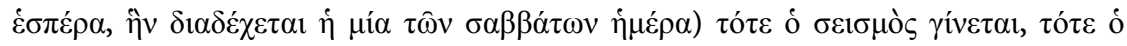

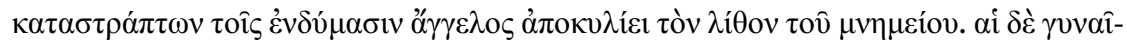

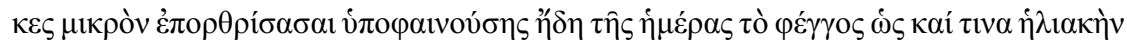

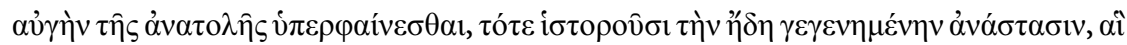

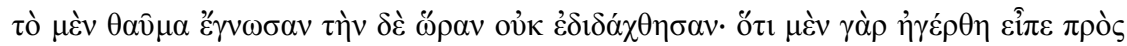

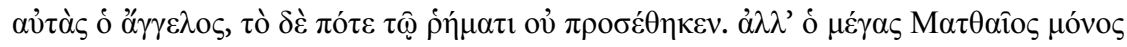

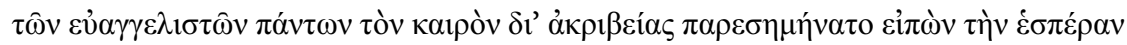

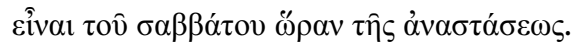

Now, look up the resurrection hour, and you will find the truth in what has been said. When did it occur? 'Late on the sabbath' (Matt 28:1), asserts Matthew. This is your hour of resurrection, according to the precise statement of the Gospel, this is the end of the Lord's stay in the "Heart". For when it was already well into the evening - and the evening was the beginning of that night, which is followed by the first day of the week - then the earthquake occurs, then the angel in brilliant raiment rolls away the stone from the tomb. And the women, getting up early when day was already beginning to show a little light so that a ray of sunrise was appearing, then recount the resurrection which has already happened. They knew the miracle, but had not been taught the time of it; for the angel told them that he had risen, but did not go on to say when. Great Matthew is alone among all the evangelists in indicating the time exactly, saying that the evening of the Sabbath was the hour of resurrection (Trid. spat. 289,4-19).

The adjective $\mu \varepsilon \gamma_{\alpha \varsigma}$ to refer to Matthew is rather unusual, even if it is found in the poems of Gregory of Nazianzus, especially when dealing with the

37 Drobner, Die drei Tage, 106-8.

38 Homilia cathedralis 77 (CPG 7035); M.A. Kugener/E. Triffaux, Les Homiliae cathedrales de Sévère d'Antioche (suite): homélie LXXVII. Texte grec édité et traduit en français; versions syriaques publiées pour la première fois (Patrologia Orientalis 16.5; Paris, 1922). 
genealogy of Matt 1. Its use here gives a hint of the process of legitimation: ${ }^{39}$ Gregory needs to support his solution by enhancing the value of the testimony he has chosen. But once again, he uses the resurrection stories without telling them again. He just supposes that his audience already knows the different elements from the four versions of the Gospels. He rather focuses on finding a solution that suits his own interpretation of the three days between death and resurrection.

To sum up: the resurrection stories proper do not have a central place in the Easter homilies; they are an important part of his Easter preaching, but they are neither his main theme nor his structuring thread. Gregory uses them as part of his preaching; he rewrites and interprets them, but they seem to be scriptural proofs for a theological aim, or at least evidence for an exegetical demonstration, rather than stories that need and merit to be told again. Scripture is then used to solve the problem, not to tell the story once again.

\section{From Paul to Gregory: Rewriting and Theology}

In sanctum Pascha deals with the resurrection of the faithful and introduces another core text: 1 Cor 15 . The central part of this homily offers a general presentation of the resurrection. It is not the only work in which Gregory deals with this topic: De anima et resurrectione and a large section of De hominis opificio (chap. 21-27) also deal with it. The latter work should be dated after the death of Basil of Caesarea (autumn 378) and before Gregory's brother Peter became the bishop of Sebasteia; so the work is generally dated from 379. De anima et resurrectione is much more difficult to date. ${ }^{40}$ But as T.J. Dennis has shown, ${ }^{41}$ it is almost impossible to establish a chronology between In sanctum Pascha and the two other works, since the author does not handle the theme in similar ways. Dennis argued that the sermon has nothing new to offer for apologetics; it is a simple work that does not go deep in philosophical questions, contrary to De hominis opificio and De anima et resurrectione; even if this last position is probably too radical, the first point is convincing: the literary genres are too different to allow precise comparisons and relative date.

The central section of In sanctum Pascha has nothing to do with the resurrection stories in the gospels: no mention of the women, of the tomb or of the apparitions. The focus is clearly on the resurrection of the human being,

39 In late Antiquity the phrase is only found here and in Gregory of Nazianzus, Poems, I.1.18, v. 89; II.1.19, v. 92; Pseudo-Caesarius, Quaestiones et responsiones, 198,42. There are a few more occurrences in Byzantine texts. On the use of qualifying adjectives for the names of biblical authors in Gregory, see Cassin, L'écriture de la controverse, 209-12.

40 See above n. 16-17.

41 T.J. Dennis, “Gregory on the Resurrection of the Body”, in Spira/Klock (ed.), The Easter Sermons of Gregory of Nyssa, 55-80, on p. 74. 
hence on the Last Judgement and not on Easter. The best parallels are with 1 Cor 15 that is both quoted (see Sanct. Pasch. 259,18-22) and used as a direct inspiration (examples of the wheat grain and of the potter).

A little later in the homily $(264,3-266,8)$, Gregory develops another point, arguing from the link between resurrection, and reward and retribution. The last part of the central development deals with the necessity of resurrection for the Last Judgment and universal justice. This theme has no direct support in 1 Cor 15, and Gregory in fact slightly alters Paul's aim when he quotes 1 Cor 15:32, "Let us eat and drink, for tomorrow we die". In Paul's letter, this quotation from Isaiah (Is 22:13) is cited as an argument in favour of the resurrection, of faith in Christ's resurrection; Gregory uses the verse in a larger demonstration on the immorality of life without resurrection. For Paul, it is a question of personal faith and of the validity of present life (and death); for Gregory, it is a matter of moral life and the Last Judgment. Perhaps more than 1 Cor, it is Matthew's parable of the Last Judgment (Matt 25:31-46) that is in the background of the last part of this homily. These texts are familiar to Gregory, who also uses them in his homilies on poverty (De beneficentia and In illud, quatenus uni ex his fecisti). ${ }^{42}$

So even when Gregory has at hand a New Testament text that offers him a framework for his homily, such as 1 Cor 15 , he does not directly use it and rather builds a separate and coherent argumentation, where he of course quotes some verses from the biblical substrate, but without using it as his guide and structure. Previous theological discussions on resurrection, such as the debate between Origen and Methodius of Olympus, influenced him more directly, it seems, than New Testament texts, as far as the composition of his homily is concerned. But the New Testament model is in the background and pops up here and there.

\section{Liturgical Celebration of the Resurrection}

After theology, what about liturgy? In sanctum Pascha offers a place where the audience - or reader - touches immediately the discrepancies between Gregory's presentation of Easter and the biblical content of the feast, both in the Old and the New Testament. The last part of the prologue starts from a psalm verse (Ps 117:24), and develops into a description of the earth and human beings totally transformed by the feast $(249,1-250,2)^{43}$. There is not one New Testament element in this description. The only biblical support comes from Gen 40:20-21, the episode of the baker and the cupbearer in Joseph's story, which is not at all an Easter text.

42 Benef. 99,12-101,17; Quat. uni 111,5-112,7; 121,11-122,8.

43 See Harl, "L'éloge de la fête", 88-91. 
But elsewhere, Gregory directly bases his liturgical and exhortative purpose on New Testament materials that have a link with Easter. At the end of De tridui spatio, the author all of a sudden introduces the resurrection.

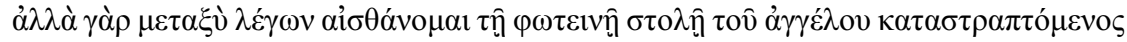

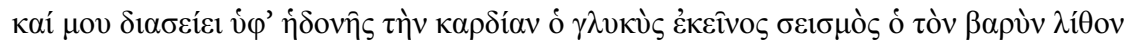

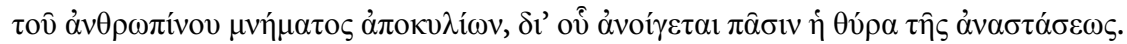

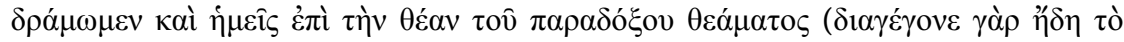

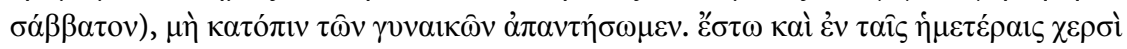

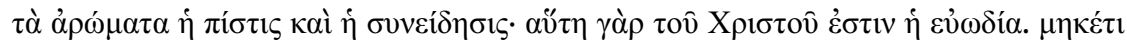

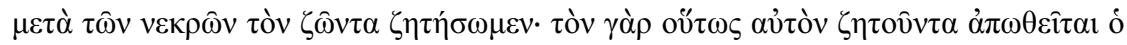

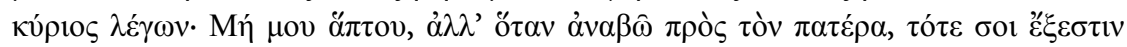

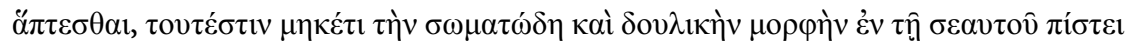

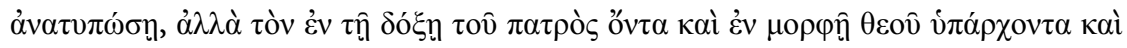

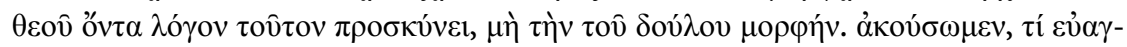

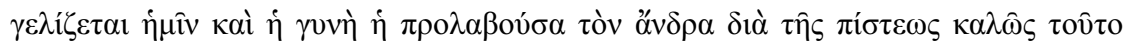

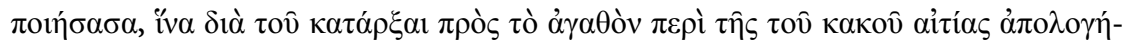

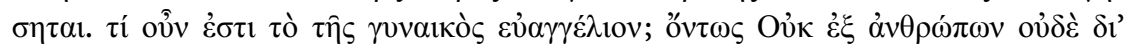

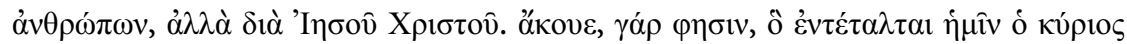

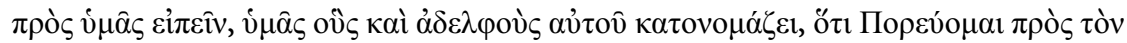

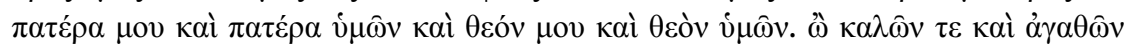

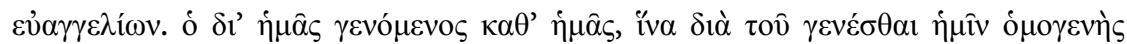

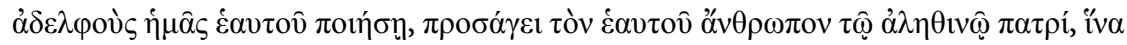

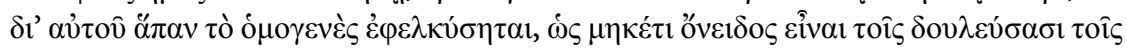

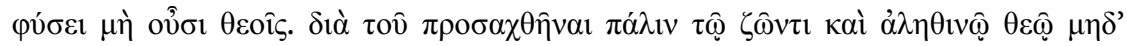

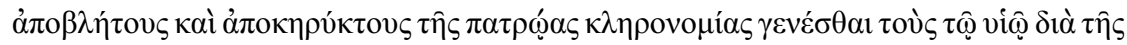

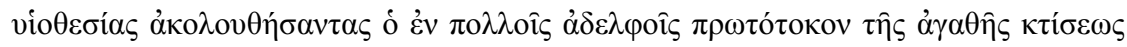

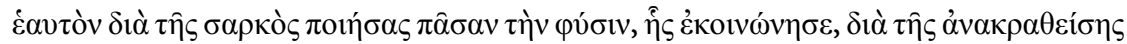
$\alpha$

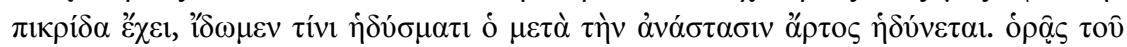

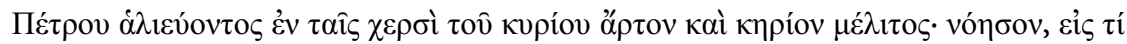

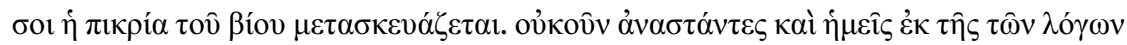

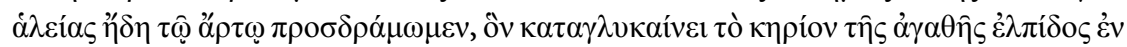

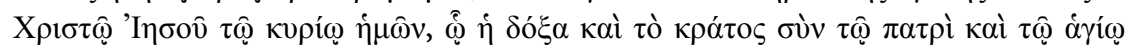

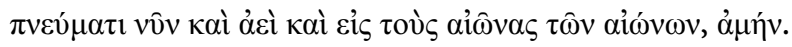

But even as I speak I sense myself lit up by the luminous robe of the angel, and that sweet earthquake shakes my heart with pleasure, rolling away the heavy stone of the human tomb, through which the door of resurrection is opened to all. Let us also run to see the amazing sight (for already the Sabbath is passed), or we may arrive after the women. Let the spices in our hands be faith and conscience; for this is the sweet savour of Christ. Let us no longer seek the living among the dead. The one who seeks him like that the Lord rejects, and says, "touch me not, but when I have ascended to the Father, then you will be able to touch me" (John 20:17). That means, "Do not imagine any more in your faith the bodily and servile form, but the one that is in the 
glory of the Father and exists in the form of God and is God's Word, him you must worship, not the form of the servant". Let us hear what good news is told us by the woman who anticipated the man, doing this surely through faith, in order that by initiating the movement toward goods she might make amends for the causing of evil. What then is the woman's news? Truly "not from men nor through men, but through Jesus Christ" (Gal 1:1). For "Listen", she says, "to what the Lord has commanded us to tell you, you whom he also calls his brothers; 'I am going to my Father and your Father, and my God and your God"' (John 20:17). O happy good news! He who for us became one of us, so that by becoming our kin he might make us his own brothers, he brings his own Man to the true Father, in order through him to attract all that is akin, so that there is no more reproach against those who have been slaves to the truly unreal gods. Because those who through adoption have followed the Son have been brought near again to the living and true God and have not become rejects and exiles from the paternal inheritance, he who through the flesh made himself firstborn of the good creation among many brothers (Col 1:15; Rom 8:29) has drawn upon him the whole nature in which he has shared through the flesh commingled with him. But since the pre-paschal unleavened bread has bitter herb for relish, let us see the sweetening with which the post-resurrection bread is sweetened. As Peter fishes, you see bread and honeycomb in the Lord's hand; consider what the bitterness of your life is transformed into. So let us also rise up from the fishing of words and make haste now to the bread, which is sweetened with the honeycomb of good hope in Christ Jesus our Lord; to whom be glory and power with the Father and the Holy Spirit now and ever and to the eternal ages. Amen (Trid. spat. 304,5-306,10).

The epilogue is explicitly presented as an interruption of the on-going speech ( $\left.\mu \varepsilon \tau \alpha \xi \dot{v} \lambda \varepsilon^{\prime} \gamma \omega v, 304,5\right)$. Gregory describes this event with words that are directly borrowed from the Resurrection stories: the angel ( $\tau \circ 0 \hat{\alpha} \alpha \gamma \gamma \varepsilon \hat{\varepsilon} \lambda \mathrm{ov)}$ ), the

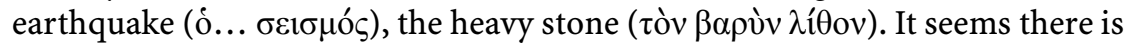
only one discrepancy: it is the earthquake that rolled away the stone (304,7-8:

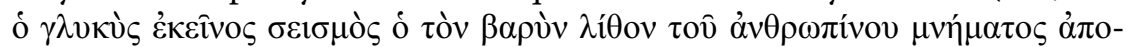
$\kappa v \lambda i \omega v)$, and not the angel, contrary to Matt 28:2. ${ }^{44}$ These five first lines (304,5-9) give the general tone of the epilogue: the resurrection stories are rewritten in order to introduce the audience instead of the women and apostles; the orator tries to actualize in the liturgy the very process of the resurrection stories.

Drobner has already shown that Gregory changes his expression in this last part of the speech by moving to the $1^{\text {st }}$ person plural. ${ }^{45}$ This change is consistent evidence in favour of my interpretation, since it offers an indication that Gregory tries to integrate his audience in the story. He also shifts to the subjunctive mood in $1^{\text {st }}$ person plural, as a collective exhortation: see $\delta \rho \alpha ́ \mu \omega$ -

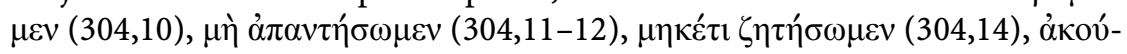

44 It's this gospel form that is also used earlier in the same homily: Trid. spat. 289,10-11. Other

Gospels do not give any hint on the origin of the movement of the stone.

45 Drobner, Die drei Tage, 159. 
$\sigma \omega \mu \varepsilon v(304,21)$. This entire paragraph is written as a paraphrase of the Gospels' accounts on the morning of resurrection, with a few Pauline

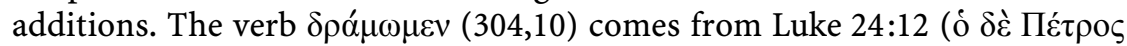

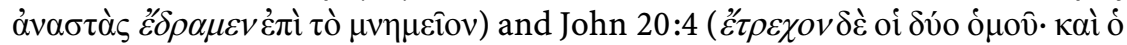

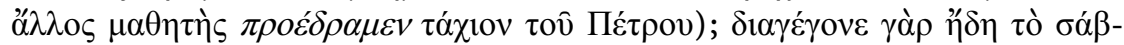

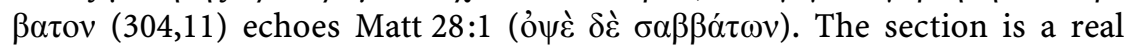
patchwork of New Testament texts about the Easter Sunday morning, but in a form of cento: it seems that the author has no particular Gospel in mind. Gregory freely composes his epilogue picking up bits and pieces from all of the Gospels.

Moreover, he also inserts directly in the story Pauline interpretations, for example with regard to the spices, which are read as faith and clear conscience

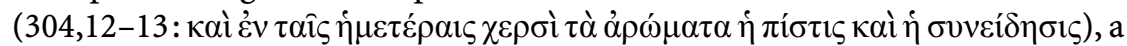

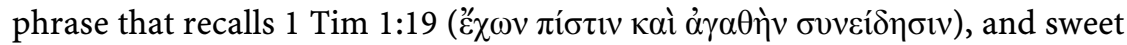

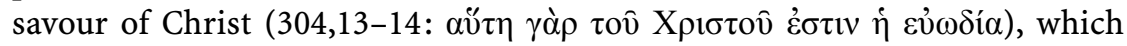

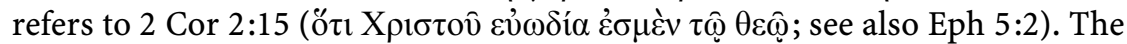

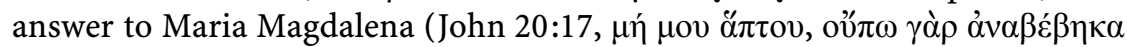
$\pi \rho \grave{\varsigma} \varsigma$ òv $\pi \alpha \tau \varepsilon \dot{\varepsilon} \rho$ ) is also rewritten and explained through Phil 2:6-7 (ô $\delta$ \& $v$

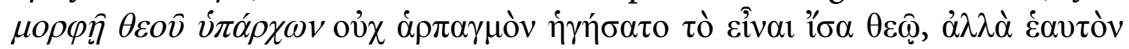

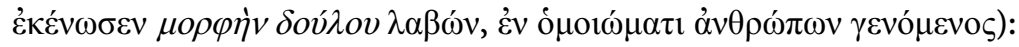

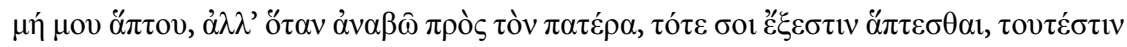

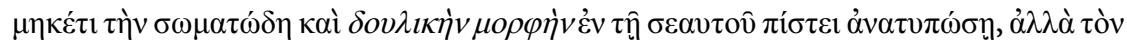

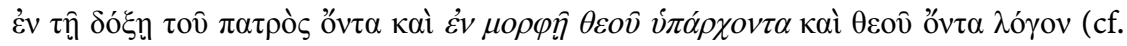

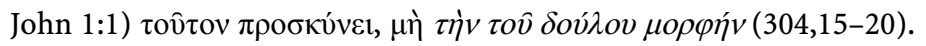

The last paragraph introduces the audience to the Eucharist proper. Gregory builds a careful transition from the discussion on unleavened bread and bitter herb from the last part of speech to the new Easter bread. He intertwines two apparition stories. One comes from John 21 (Peter is fishing and Jesus has fish in his hands), the other is a variant of Luke $24: 42$, which adds to the traditional

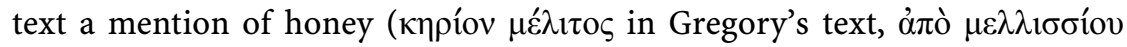
$\kappa \eta \rho i ́ o v$ in Luke's variant reading). ${ }^{46}$ It seems to be a testimony of a baptismal

46 For a presentation of this variant and its story, see Drobner, Die drei Tage, 165-6 and n. 713 for previous bibliography; G.D. Kilpatrick, "Luke 24:42-43", NovT 28 (1986) 306-8; F. Bovon, L'évangile selon saint Luc (19,28-24,53) (Commentaire du Nouveau Testament, 2 e série, IIId; Genève, 2009), 466. See also B. Cherubini, "Mangiò pesce miele": un antica tradizione sul risorto (Tesi di Laurea, Università Roma Tre, 2006). See E. Nestle, “The Honeycomb in Luke XXIV”, ExpT 22 (1911) 567-8. This variant is attested in patristic authors from at least the 2nd century: (Justin), De resurrectione, 9,7 (for the interpretation of this passage, see M. Heimgartner, Pseudojustin: Über die Auferstehung, Text und Studie [PTS 54; Berlin/New York, 2001], 86, 199); Tertullian, De corona, 3; Clemens of Alexandria, Paedagogus, 2,1,15,2-3; and directly from the 4th century onward: Cyril of Jerusalem, Cat. 14, 11; Epiphanius, Panarion, 66,39,2; Amphilochius of Iconium, Contra haereticos, 27, 1055; Pseudo-Athanasius, Oratio IV contra arianos, 35,28-29; Cyril of Alexandria, In Joannem, III, 150,8-10. This variant reading is largely present in New Testament manuscripts: see K. Aland/ B. Aland/K. Wachtel, Text une Textwert 
practice, when newly baptised received at the first Eucharist not only bread and wine, but also milk and honey as a sign of their entering into the promised land. ${ }^{47}$ The two accounts are perhaps mixed for a liturgical reason: the community where Gregory preached this homily possibly used to offer milk and honey to the newly baptised; honey can be added up with bread, but not with fish as in Luke's Gospel. But there is also a rhetorical reason: Gregory needs bread in order to close up his speech, reminding his previous part about unleavened bread. He also uses the direct context of John 21, the fishing party of the apostles, since he adds another image to this very end of the prologue, saying:

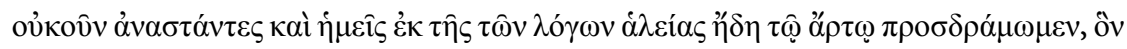

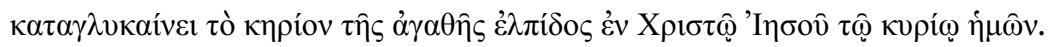

So let us also rise up from the fishing of words and make haste now to the bread, which is sweetened with the honeycomb of good hope in Christ Jesus our Lord (Trid. spat. 306,5-8).

So John 21 is read as a typos of the Eucharist as a whole: first, hear readings from the Ancient and New Testament, and try to understand and interpret them, what Gregory calls 'fishing', and then run to the shore to meet Christ and eat bread with him, which is the Eucharist proper. Moreover, there is an exegetical and theological need for honey here, since Gregory reads this meal as the New Testament counterpart to the paschal meal of unleavened bread and bitter herbs: so to the unleavened bread he opposes the bread of Christ, and to the bitter herbs, the honeycomb. It is a usual opposition between desert and Holy land, between exile and the land of Promise. So the composite citation is a direct counterpart of Gregory's theological exegesis of Easter, in a context of the Eucharist.

We find a similar conflation of John 21 and Luke 24:42 with the variant reading in the Homilies on the Song of Songs (X, 306,7-307,8):

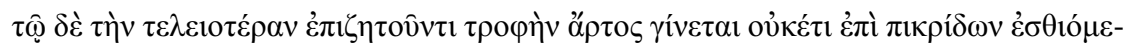

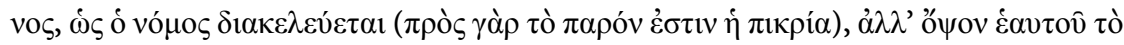

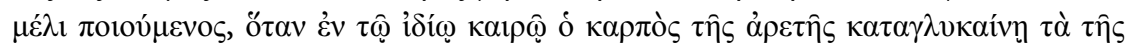

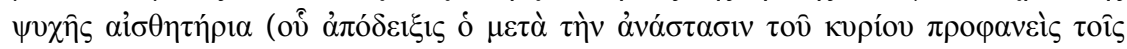

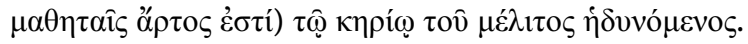

Then for the one who is seeking more perfect nourishment, they [the plants] become bread, and it is no longer eaten with "bitter herbs" (Exod 12:8) as the law commands

der griechischen Handschriften des Neuen Testaments. IV, Die synoptischen Evangelien. 3, Das Lukasevangelium. 3.1, Resultate der Kollation und Hauptliste sowie Ergänzungen (Arbeiten zur neutestamentlichen Textforschung 31; Berlin/New York, 2003), 131-2.

47 Drobner, Die drei Tage, 166-7. See also P.M. Gy, "Die Segnung von Milch und Honig in der Osternacht", in B. Fischer/J. Wagner (ed.), Paschatis solemnia. Studien zu Osterfeier und Osterfrommigkeit (FS Josef Andreas Jungmann; Basel/Freiburg/Wien, 1959) 206-12. 
(since the bitterness is for now) but with honey as its relish, whenever, in its own season, the fruit of virtue conveys a sweetness to the soul's senses, which is demonstrated by the bread that was manifested to the disciples after the Lord's resurrection, sweetened by the honeycomb (John 21:9 and Luke 24:42) (Cant. X, $306,17-307,5) .^{48}$

Here, the parallel of bread and honey is required by the very text of the Song of Songs, since Cant 5:1 reads:

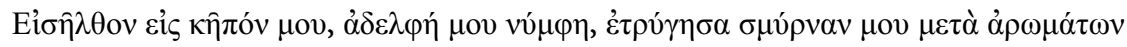

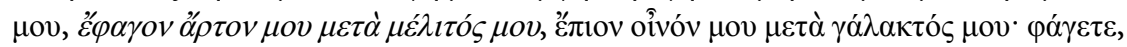

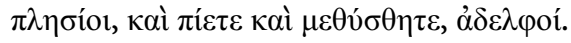

Drobner had already suggested a link between this passage and De tribui spatio, but only on the basis of the interpretation of the bitter herbs. ${ }^{49}$ He does not indicate that Gregory also uses the conflation of John 21 and the variant of Luke 24:42 in this passage of the Homily on the Song of Songs. Since the link between bread and honey is present in the Song of Songs text, it seems that the Homilies are the proper place to conflate John 21 and the variant of Luke 24:42; if this interpretation is correct, it may indicate that De tridui spatio is posterior or contemporaneous to the homilies (so at the very end of Gregory's life). ${ }^{50}$ It is at least sure that the two texts are closely linked together, since both homilies have the main tread that leads from bitter herbs to Eucharist and mystical union with Christ.

The whole epilogue of De tridui spatio is built upon a transversal reading of the resurrection stories from the four Gospels, or rather a cento reading that picks up bits and pieces from one or the other Gospel according to a general aim even if it means to transform resurrection stories themselves, as we have seen with John 21 and Luke 24. This cento is however interpreted in a liturgical and Eucharist context; the speech is explicitly written in order to bring in the audience in both the story and the liturgy, so as to have them fully take part in liturgical action. The homily is, so to say, a transition from Bible reading to the Eucharist proper.

48 Translation R.A. Norris, Gregory of Nyssa: Homilies on the Song of Songs (Writings from the Greco-Roman World 13; Atlanta, GA, 2012), 323, with modifications. I interpret the text and modify the punctuation of the editor, H. Langerbeck, according to the interpretation and comment of A. Rousseau, Grégoire de Nysse, Homélies sur le Cantique des cantiques (Bruxelles, 2008), 226 and n. 1.

49 Drobner, Die drei Tage, 166, n. 705.

50 See F. Dünzl, Braut und Bräutigam: die Auslegung des Canticum durch Gregor von Nyssa (BGBE 32; Tübingen, 1993), 30-3. 


\section{Conclusion}

I have proposed in this paper a general survey of the usages of resurrection stories from the New Testament in the three authentic homilies on Easter by Gregory of Nyssa. It is no surprise that Gregory quotes and comments on these stories. But they are not the centre and main topic of his homilies. The two main ones, In sanctum Pascha and De tridui spatio, in different ways, are clearly too elaborated to be simple and linear comments on the Gospel texts. De tridui spatio has obvious exegetical aims, but they are inserted in a larger theological frame and in an already elaborated exegetical tradition, for example, about the three days of Christ's death. The case of In sanctum Pascha is even clearer: the reflexion on resurrection is largely disconnected from New Testament texts; of course, Easter offers the occasion to speak about resurrection, but Gregory's way of talking about it has little to do with the Gospel accounts and more with an already established tradition, or rather with an on-going debate about resurrection that starts with the Apologists and finds a new starting point in the dispute between Origen and Methodius of Olympus. Resurrection is here seen as resurrection of human beings, and not mainly as resurrection of Christ.

So the resurrection stories are clearly part of these homilies and the preacher was right to suppose his audience already knows them. However, they are not his object and theme when preaching about Easter, at least not in the homilies that have come down to us. But they are used - with modifications and rewriting - in order to conduct the audience from hearing to taking part in liturgical action. 
(C) 2016, Vandenhoeck \& Ruprecht GmbH \& Co. KG, Göttingen ISBN Print: 9783525593745 — ISBN E-Book: 9783647593746 